\title{
Erratum to: Antibiotics in food: Legislation and validation of analytical methodologies
}

\author{
R. Companyó • M. Granados • J. Guiteras • M. D. Prat
}

Published online: 30 October 2009

(C) Springer-Verlag 2009

\section{Erratum to: Anal Bioanal Chem}

DOI 10.1007/s00216-009-2969-4

The article was published in Vol. 395, issue 4, on pages 877-891. Recently, the authors became aware that Regulation (EEC) no. 2377/90 was repealed by Regulation (EC) no. $470 / 2009$.

The correct version of the first row of Table 1 on page 879 is given here:

Table 1 Main legislative documents of the EU (in chronological order)

\begin{tabular}{|c|c|c|c|}
\hline Document & Title & Field & Reference \\
\hline $\begin{array}{l}\text { Regulation } \\
\text { (EC) no. } \\
470 / \\
2009\end{array}$ & $\begin{array}{l}\text { Laying down Community } \\
\text { procedures for the } \\
\text { establishment of residue limits } \\
\text { of pharmacologically active } \\
\text { substances in foodstuffs of } \\
\text { animal origin }\end{array}$ & $\begin{array}{l}\text { Maximum } \\
\text { residue } \\
\text { limits }\end{array}$ & {$[31]$} \\
\hline
\end{tabular}

Also, in the text on page 880 three corrections need to be made:

Line 2: incorrect: 2377/90, correct: 470/2009.

Line 23: "or Annex IV of Regulation 2377/90" should be deleted.

Line 43: "Regulation 2377/90 and" should be deleted.

The correct reference 31 should read:

Council of the European Union (2009) Off J Eur Union L 152:11

The online version of the original article can be found at http://dx.doi. org/10.1007/s00216-009-2969-4.

R. Companyó $(\bowtie) \cdot M$. Granados $\cdot$ J. Guiteras $\cdot$ M. D. Prat Departament de Química Analítica, Facultat de Química, Universitat de Barcelona, c/Martí i Franquès 1-11, 08028 Barcelona, Spain e-mail: compano@ub.edu 